\title{
Vegetation structure, biomass and carbon retention capacity of mangroves at Northeast coast of Sri Lanka
}

K.A.R.S. Perera* and M.D. Amarasinghe*

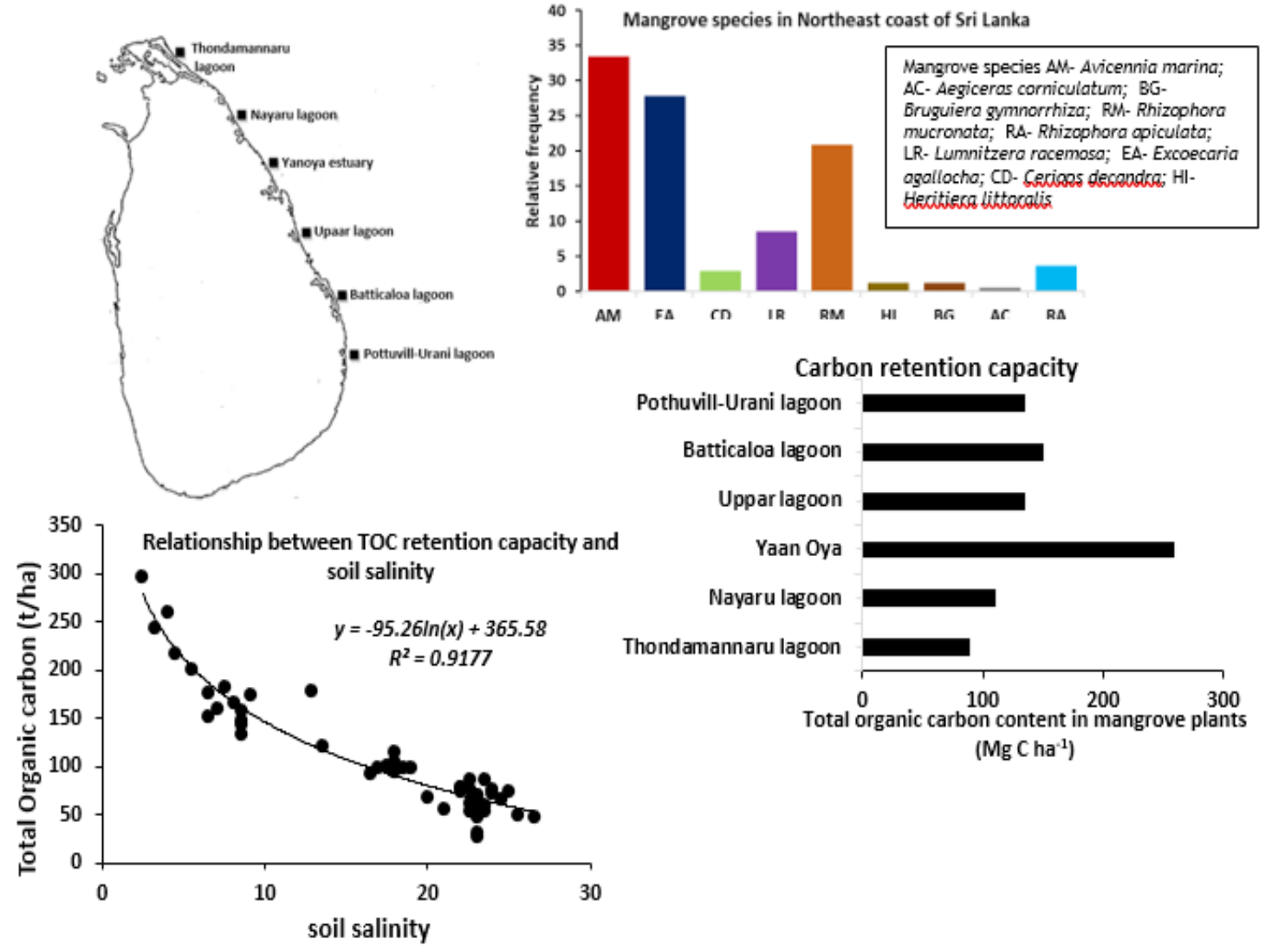

\section{Highlights}

- Highest mangrove diversity was at Yan Oya followed by Thondamannaru and Uppar lagoons.

- A critically endangered mangrove species, Ceriops decandra was recorded at Yan Oya.

- Relatively higher biomass values (159-460 $\mathrm{Mg} \mathrm{ha}^{-1}$ ) recorded at Yan Oya estuary.

- Average above ground biomass of the northeast coast of Sri Lanka was $226.34 \mathrm{Mg} \mathrm{ha}^{-1}$.

- Relationship was revealed between soil salinity and TOC retention in mangroves. 


\title{
RESEARCH ARTICLE
}

\section{Vegetation structure, biomass and carbon retention capacity of mangroves at Northeast coast of Sri Lanka}

\author{
K.A.R.S. Perera ${ }^{1, *}$ and M.D. Amarasinghe ${ }^{2}$ \\ ${ }^{1}$ Department of Botany, The Open University of Sri Lanka, Nawala, Nugegoda, Sri Lanka \\ ${ }^{2}$ Department of Botany, University of Kelaniya, Kelaniya, Sri Lanka
}

Received: 19/10/2020; Accepted: 20/04/2021

\begin{abstract}
Mangroves represent one among the most carbon retaining ecosystems in the world, due to their high productivity and huge carbon sinking capacity within biomass and substratum. Majority of Sri Lankan mangroves are located on the northeastern coast. Since they were highly isolated during the last three decades, there are limited research publications related to those. Present study was conducted at six major mangrove ecosystems in the northeast coast of Sri Lanka with the objectives of reporting the present vegetation structure and to estimate their capacity of the carbon pool with plant biomass. Highest mangrove diversity was recorded at Yanoya followed by Thondamannaru and Uppar lagoons. A critically endangered mangrove species, Ceriops decandra, was recorded at Yanoya mangrove ecosystem, this may be the first-time scientific record of the species in the recent history. Relatively higher biomass values (159 - 460 $\mathrm{Mg} \mathrm{ha} \mathrm{a}^{-1}$ ), recorded at Yanoya estuary. The average value for above ground biomass of the northeast coast of Sri Lanka was 226.34 Mg ha ${ }^{-1}$. Statistically significant linear relationships occurred between the biomass and the mangrove vegetation structure, as well as between the soil salinity and the carbon retention capacity of mangrove. Results of the present study assist to add new knowledge and rationalize the conservation and proper management of mangrove ecosystems on the northeast coast of Sri Lanka.
\end{abstract}

Keywords: Vegetation structure; biomass; carbon retention capacity; mangroves.

\section{INTRODUCTION}

Mangrove forests are critical inhabitants of the border line between land and the sea, being key ecosystems in many tropical and subtropical coastlines of the world. They are true ecotones, being not just transitional in nature, containing some elements of terrestrial as well as marine ecosystems. Mangroves exist in conditions of high salinity, inundations by tides, strong winds, high temperatures with direct sunlight and anaerobic muddy soils. They have suitable adaptations for all these stresses and no other group of flowering plants with such highly developed morphological and physiological adaptations to such extreme conditions (Kathiresan et al., 2015).

Mangroves are important with their ecological, economic, and social values and services (Saenger, 2002;
Lacambra et al., 2013;). In addition to common economical and social services, recent research revealed that mangroves are one among the world's most productive ecosystems, assimilating organic carbon well in excess of the ecosystem requirements and substantially contributing to the global carbon cycle (Kathiresan et al., 2015). The carbon sequestration capacity of this highly productive ecosystem is a function of biomass accumulation. It was proved that interactions between physical, chemical, climatic and topographic elements depends on the accumulation of plant biomass (Kirui et al., 2006).

Total estimates on the global extent of mangroves nearly 17 million ha (Aizpuru et al., 2000) distributed among 121 countries in the world (Spalding et al., 1997). The precise number of species is still under debate and recorded range from 50 to 70, according to different classifications (Lugo and Snedaker, 1975; Saenger, et al., 1983; Tomlinson, 1986; Aksornkoaeet al., 1992), and Asian region followed by the eastern Africa recorded the highest diversity of mangroves.

Due to the geographical location of Sri Lanka, overall climate of the island characterized as tropical and recorded high biodiversity mangrove areas comprised of twenty-five (25) true mangrove species and thirty-four (34) mangrove associated plant species (Amarasinghe and Perera, 2017). Based on the prevailing annual rainfall, three main climatic zones, wet, intermediate and dry zone are identified. The climatic pattern of Sri Lanka is mainly determined by the creation of monsoonal wind patterns in the surrounding oceans. The coastline of Sri Lanka is approximately 1338 $\mathrm{km}$ long (Silva et al., 2013) and more than $70 \%$ of coastline is located in the dry climatic zone where receiving of annual rainfall is less than $1750 \mathrm{~mm}$. Current extent of mangroves in Sri Lanka recorded as 15,670 ha, interspersing of 13 administrative districts along the coastline of the country (Edirisinghe et al., 2012; Prasanna et al., 2019). Based on the distribution of mangroves in Sri Lanka, majority are located on the northern and eastern coasts. Total of 10,515 ha, which represent the $67 \%$ of the total mangrove extent is restricted to northern and eastern coasts. District wise breakdown of mangrove extent was reported as, 618 ha at Ampara, 2,071 ha at Batticaloa, 2,505 ha at Jaffna, 1,885 ha at Kilinochchi, 1,041 ha at Mullaitivu, and 2,395 ha at 
Trincomalee (Edirisinghe et al., 2012). These areas were highly isolated during last thirty years due to the war situation of the country and limited research data were available on coastal ecosystems of such areas. Therefore, the present study was conducted with the objectives of reporting the present vegetation structure and estimating their capacity of carbon pool with plant biomass at six major mangrove ecosystems, Thondamannaru lagoon, Nayaru lagoon, Yanoya estuary, Batticaloa lagoon, Uppar lagoons and Pottuvill-Urani lagoon, found along the north east coast of Sri Lanka.

\section{MATERIALS AND METHODS}

\section{Study areas}

Study was conducted in six (06) mangrove areas along the northern, northeastern and eastern coastal zones of Sri Lanka. Coastal zones were classified according to Silva et al., (2013). Thondamannaru lagoon, Nayaru lagoon and Yanoya estuary were selected to represent the Northern coastal zone, Batticaloa, Uppar lagoons were selected to represent the Northeastern coastal zone and PottuvillUrani lagoon was selected to represent the Eastern coast of Sri Lanka (Figure 1 and Table 1). All six selected study areas are located in the dry climatic zone of Sri Lanka. Thondamannaru lagoon is in the interior of the Jaffna Peninsula and east of Jaffna District, Northern Province. Total lagoon area is recorded 7,787 ha. A shallow (about $2 \mathrm{~m}$ depth) lagoon stretching for about $45 \mathrm{~km}$ along and at the northwestern section it is connected to the Indian Ocean by a narrow channel (Kotagama, et. al., 1989; Silva et. al., 2013). Nayaru lagoon (some reference indicates as "Nai Aru" Lagoon), located in Mullaitivu District, Northern Province and the total area is 1,760 ha. The maximum depth was recorded about 3-4 $\mathrm{m}$ at the mouth of the lagoon (Kotagama, et al., 1989). The freshwater inflows through irrigation streams and the regular sandbars create barriers

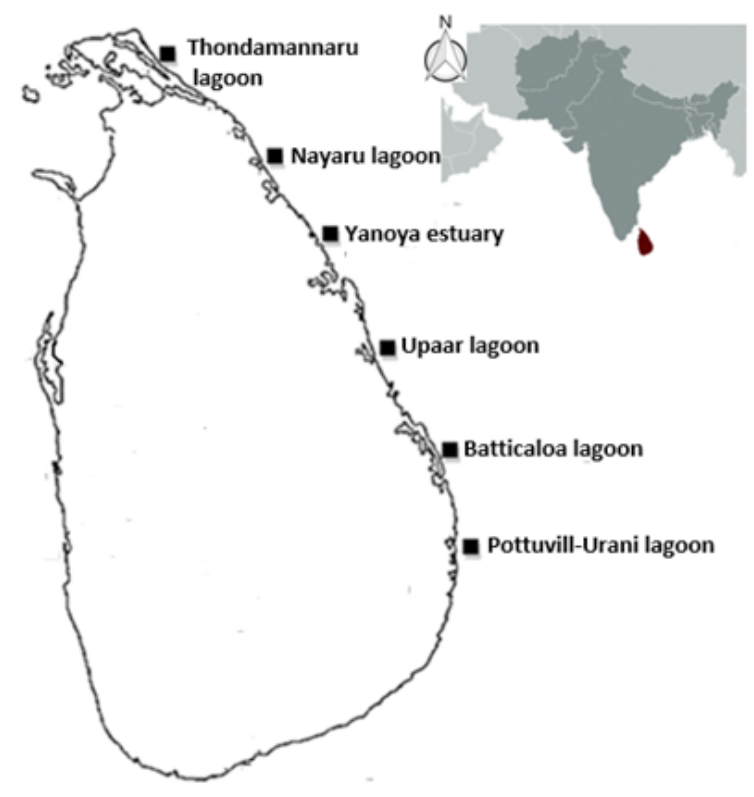

Figure 1: Locations of study areas. to the sea. Yanoya estuary is located in Trincomalee District, Eastern Province of Sri Lanka. Estuary created with the Yanoya, the fifth-longest river (approximately 142 $\mathrm{km}$ ) of Sri Lanka. Its catchment area, $1,520 \mathrm{~km}^{2}$ receives approximately 2,371 million $\mathrm{m}^{3}$ of fresh water per year. Maximum depth of about two meters (Kotagama, et al., 1989; Silva et al., 2013).

Upaar (Panichchankeni) lagoon is located in Batticaloa District, Eastern Province and lagoon area recorded around 2,590 ha. Average depth of the lagoon recorded 1-2 m and fed by number of small streams. Lagoon opens to the sea through a narrow channel at its southern end (Kotagama, et al., 1989; IUCN Sri Lanka and the Central Environmental Authority, 2006; Silva et al., 2013).

Batticaloa lagoon is located in the east coast at Batticaloa District. This is relatively large (14,118 ha.) and a deep lagoon (about $4 \mathrm{~m}$ ) which connects to the sea with two narrow channels (IUCN Sri Lanka and the Central Environmental Authority, 2006; Harris and Vinobaba, 2013). Sand bars are created by high wave action occur during the dry season, which blocks the connections to the sea. The lagoon receives fresh water from several small canals during the rainy season.

Pottuvill-Urani lagoon is located in the Ampara District, of the Eastern Province of Sri Lanka. The lagoon is connecting with the Indian Ocean by a channel found on its eastern part. There are a number of small streams joining to the lagoon with freshwater inputs. Maximum depth of the lagoon is 2-3 m, while salinity levels change seasonally and can be over 30 ppt (Kotagama, et al., 1989; IUCN Sri Lanka and the Central Environmental Authority, 2006; Silva et al., 2013).

\section{Sampling strategy}

Strata were identified along the obvious environmental gradient from estuarine shoreline and banks of the creeks towards the inland. In order to collect data on vegetation structure, $10 \mathrm{~m}$ wide belt transects were laid perpendicular to the estuarine/lagoon shoreline across the environmental gradient in randomly selected points in each study area. Two to six numbers of transects were laid in each study area. Each transect was divided into $10 \mathrm{~m} \times 10 \mathrm{~m}$ sampling plots and a total of sixty-eight (68) sampling plots were laid in all six study areas. All mangrove trees only the stem girth greater than $2.5 \mathrm{~cm}$ encountered. Trees in the study plots were identified, numbered and mapped. Girth diameter at breast height (dbh) and tree height were measured using accepted methods described by Cintron and Novelli (1984), and Kathiresan and Khan (2010) from each laid study plot $\left(100 \mathrm{~m}^{2}\right)$ at all study areas.

Basal area, stand density, stand height, mean stand diameter and complexity of index (CI) of constituent species was calculated with standard methods (Cintron and Novelli, 1984; Kathiresan and Khan, 2010; Perera and Amarasinghe, 2016).

\section{Soil salinity}

Salinity of mangrove soil was recorded for at least one transect (along the gradient) of each study area. Each 
Table 1: Study locations and their climatic characteristics

\begin{tabular}{|c|c|c|c|c|}
\hline Study area & location & 惡狊 & 总昰 & 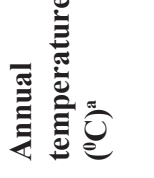 \\
\hline Thondamannaru lagoon & $9^{0} 42^{\prime} 07.28^{\prime \prime} \mathrm{N} ; 80^{\circ} 17^{\prime} 02.80 \mathrm{E}$ & 1033.3 & $83-91$ & $25.3-30.2$ \\
\hline Nayaru lagoon & $9^{0} 07^{\prime} 42.27^{\prime \prime} \mathrm{N} ; 80^{0} 51^{\prime} 49.19 \mathrm{E}$ & 1492.5 & $78-90$ & $25.8-30.2$ \\
\hline Yanoya estuary & $8^{0} 53^{\prime} 51.47^{\prime \prime} \mathrm{N} ; 81^{0} 00^{\prime} 00.25 \mathrm{E}$ & 1492.5 & $78-90$ & $25.8-30.2$ \\
\hline Uppar lagoon & $8^{0} 05^{\prime} 13.25^{\prime \prime} \mathrm{N} ; 81^{0} 26^{\prime} 15.92 \mathrm{E}$ & 1973.7 & $76-88$ & $25.8-30.5$ \\
\hline Batticaloa lagoon & $7^{0} 44^{\prime} 50.70^{\prime \prime} \mathrm{N} ; 81^{\circ} 41^{\prime} 17.67 \mathrm{E}$ & 1973.7 & $76-88$ & $25.8-30.5$ \\
\hline Pottuvill-Urani lagoon & $6^{0} 55^{\prime} 11.98^{\prime \prime} \mathrm{N} ; 81^{0} 50^{\prime} 17.29 \mathrm{E}$ & 1613.0 & $80-92$ & $26.0-29.9$ \\
\hline
\end{tabular}

Table 2: Summary of allometric relationships/ equations used to determine the above and below ground biomass of mangrove plants present in the study areas

\begin{tabular}{|c|c|c|}
\hline Mangrove species & $\begin{array}{l}\text { Allometric relationships used for determination of } \\
\text { above ground biomass (AGB) }\end{array}$ & $\begin{array}{l}\text { Allometric relationships used } \\
\text { for determination below ground } \\
\text { biomass (BGB) }\end{array}$ \\
\hline Bruguiera gymnorrhiza & $\begin{array}{l}\mathrm{AGB}=0.289(\mathrm{dbh})^{2.327} \\
(\text { Perera et al., 2012) }\end{array}$ & $\begin{array}{l}\mathrm{BGB}=0.100(\mathrm{dbh})^{2.364} \\
(\text { Perera et al., 2012) }\end{array}$ \\
\hline Lumnitzera racemosa & $\begin{array}{l}\mathrm{AGB}=0.114(\mathrm{dbh})^{2.523} \\
(\text { Perera } \text { et al., 2012) }\end{array}$ & $\begin{array}{l}\mathrm{BGB}=0.118(\mathrm{dbh})^{2.063} \\
(\text { Perera } \text { et al., 2012) }\end{array}$ \\
\hline Rhizophora mucronata & $\begin{array}{l}\log _{\mathrm{e}}(\mathrm{AGB})=6.247+2.64 \log _{\mathrm{e}}(\mathrm{dbh}) \\
(\text { Amarasinghe and Balasubramaniam, 1992) }\end{array}$ & \\
\hline Avicennia marina & $\begin{array}{l}\log _{e}(A G B)=5.551+2.153 \log _{e}(d b h) \\
(\text { Amarasinghe and Balasubramaniam, 1992) }\end{array}$ & \\
\hline Rhizophora apiculata & & $\begin{array}{l}\mathrm{BGB}=0.199 \rho^{0.899} \mathrm{dbh}^{2.46} \\
\text { (Komiyama et al., 2005) }\end{array}$ \\
\hline $\begin{array}{l}\text { Excoecaria agallocha } \\
\text { Ceriops decandra } \\
\text { Aegiceras corniculatum } \\
\text { Heritiera littoralis }\end{array}$ & $\begin{array}{l}\mathrm{AGB}=0.251 \rho \mathrm{dbh}{ }^{2.46} \\
(\text { Komiyama et al., 2005) }\end{array}$ & \\
\hline
\end{tabular}

soil sample was collected from the surface soil layer up to $5 \mathrm{~cm}$ depth and water was obtained by pressing of soil samples with a plastic syringe to obtain interstitial water and its salinity was recorded with a potable refractometer (iuchi IS-Mill-E) in the field. Mean salinity of the study plot was calculated with salinity measurements made at four randomly selected points in each study plot at selected transect.

\section{Leaf area index}

Differences between photon flux density recorded underneath of the mangrove canopy and top of the canopy/ open area was used to calculate the Leaf area index (LAI). By using LI-COR Terrestrial radiation sensor measured the photon flux densities, following the method described by Jayakody et al. (2008) and Kathiresan and Khan (2010). Gathering of solar radiation data in this study was restricted only to two study areas, Batticaloa and Uppar lagoon mangrove ecosystems.

\section{Determination of biomass and total organic carbon (TOC) in mangrove plants}

Allometric relationships developed for individual species as well as common equations were used to determine the above ground and below ground (root) biomass of mangrove plants encountered in study plots of all (06) study areas. Summary of the allometric relationships used to calculate the biomass values were presented in Table 2 .

\section{RESULTS}

\section{Mangrove vegetation structure}

Total of nine (9) true mangrove species were encountered in the study plots of all six study areas and eight (8) species each were presented in Yanoya estuary. Relatively a lesser number of true mangrove species $(2-3)$ were recorded in the sampling plots at Nayaru, Batticaloa and Uppar lagoons. In addition to that, few of true mangroves were observed in outside areas of the laid study plots of Thondamannaru lagoon. Those species are Ceriops tagal and Heritiera littoralis. Summary of the enumerated true 
mangrove species inside the sampling plots were presented in Table 2. Highest stand density was recorded at Nayaru lagoon (4,433 stems per ha), followed by Batticaloa lagoon (4,316 stems per ha) and Uppar lagoon (3,518 stems per ha). Highest mean dbh and tree height values were recorded at Batticaloa and Pottuvill-Urani lagoons, revealed that relatively large trees occurring in this area than other study areas in North-East coast of Sri Lanka. Species diversity of each study area was calculated with Shannon-Wiener index and highest diversity was at Yanoya estuary and followed by Thondamannaru and Uppar lagoons. Batticaloa mangroves recorded the highest values for complexity index (Table 3).

Above and below ground plant biomass at each sampling plot were calculated by allometric method and mean values were presented for each study areas. Biomass values were converted to the total organic carbon (TOC) contents with percentage TOC values for biomass of each mangrove species (Perera and Amarasinghe, 2016). Above and below ground highest biomass as well as TOC values were recorded at Yanoya estuary, followed by Batticaloa and Uppar lagoon mangroves (Table 4).

Species wise TOC content at different study areas was calculated. Percentage contribution of each mangrove species for the total TOC retention capacity of the study area was determined. All study areas, except Batticaloa and Pottuvill-Urani Lagoon, Avicennia marina was the highest contributing species for the TOC retention (Table 5).

A statistically significant $(\mathrm{p}<0.05)$ positive linear relationship was revealed to occur between vegetation structural complexity (CI) and total biomass of mangroves (Figure 2).

Table 3: Mangrove community structural variables recorded at six study areas

\begin{tabular}{|c|c|c|c|c|c|c|c|}
\hline Study area & 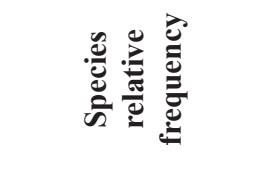 & 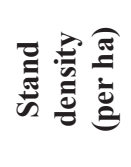 & 咅 & 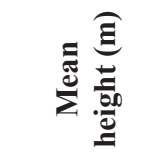 & 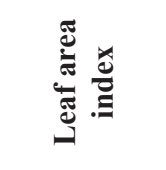 & 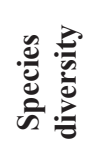 & 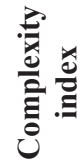 \\
\hline $\begin{array}{l}\text { Thondamannaru } \\
\text { lagoon }\end{array}$ & $\begin{array}{l}\text { AM (50\%); RM } \\
(15 \%) ; \text { LR }(26 \%) ; \\
\text { EA }(9 \%) ;\end{array}$ & 2033 & $\begin{array}{c}8.86 \\
(5.9-16.1)\end{array}$ & $\begin{array}{c}4.84 \\
(1.5-7.0)\end{array}$ & $* *$ & 0.94 & 3.20 \\
\hline Nayaru lagoon & $\begin{array}{l}\text { AM (54\%); RM } \\
(46 \%)\end{array}$ & 4433 & $\begin{array}{c}8.68 \\
(8.5-8.7) \\
\end{array}$ & $\begin{array}{c}4.48 \\
(3.5-10.5) \\
\end{array}$ & $* *$ & 0.68 & 12.61 \\
\hline Yanoya estuary & $\begin{array}{l}\text { AM }(28 \%) ; \text { EA } \\
(26 \%) ; \text { CD }(17 \%) ; \\
\text { LR }(9 \%) ; \text { RM } \\
(7 \%) ; \mathrm{HI}(7 \%) ; \\
\text { BG }(3 \%) ; \\
\text { AC }(3 \%)\end{array}$ & 2333 & $\begin{array}{c}9.5 \\
(3.6-19.6)\end{array}$ & $\begin{array}{c}4.88 \\
(1.5-13.0)\end{array}$ & $* *$ & 1.80 & 24.91 \\
\hline Uppar lagoon & $\begin{array}{l}\text { AM (65\%); RM } \\
(18 \%) ; \mathrm{LR}(16 \%) ; \\
\text { EA }(1 \%)\end{array}$ & 3518 & $\begin{array}{c}6.83 \\
(4.6-7.9)\end{array}$ & $\begin{array}{c}5.55 \\
(3.6-8.0)\end{array}$ & $5.47 \pm 0.24$ & 0.93 & 17.50 \\
\hline Batticaloa lagoon & $\begin{array}{l}\text { EA (74\%); RA } \\
(22 \%) ; \text { AM (4\%) }\end{array}$ & 4316 & $\begin{array}{c}10.71 \\
(7.4-13.4)\end{array}$ & $\begin{array}{c}6.79 \\
(4.8-10.8)\end{array}$ & $5.39 \pm 0.21$ & 0.68 & 25.90 \\
\hline $\begin{array}{l}\text { Pottuvill-Urani } \\
\text { Lagoon }\end{array}$ & $\begin{array}{l}\text { EA (57\%); RM } \\
(39 \%) ; \mathrm{BG}(4 \%)\end{array}$ & 1683 & $\begin{array}{c}10.67 \\
(8.8-11.7)\end{array}$ & $\begin{array}{c}6.94 \\
(3.0-12.0)\end{array}$ & $* *$ & 0.81 & 8.94 \\
\hline
\end{tabular}

AM - Avicennia marina; AC - Aegiceras corniculatum; BG - Bruguiera gymnorrhiza; RM - Rhizophora mucronata; RA - Rhizophora apiculata; LR - Lumnitzera racemosa; EA - Excoecaria agallocha; CD - Ceriops decandra; HI - Heritiera littoralis

** - Data not available

Table 4: Mean biomass and total organic (TOC) carbon content in above and below ground components of mangrove plants at six study areas

\begin{tabular}{lcccc}
\hline \multirow{2}{*}{\multicolumn{1}{c}{ Study area }} & \multicolumn{2}{c}{ Biomass $\left(\mathbf{M g ~ h a}^{-1}\right)$} & \multicolumn{2}{c}{ Total organic carbon $(\mathbf{M g ~ C ~ h a - 1})$} \\
\cline { 2 - 5 } & Above ground & Below ground & Above ground & Below ground \\
\hline Thondamannaru lagoon & $131.78 \pm 12.40$ & $27.75 \pm 2.61$ & $74.19 \pm 6.23$ & $15.18 \pm 1.62$ \\
\hline Nayaru lagoon & $189.51 \pm 8.91$ & $40.07 \pm 3.59$ & $91.07 \pm 4.63$ & $19.15 \pm 1.73$ \\
\hline Yanoya estuary & $386.69 \pm 7.33$ & $74.30 \pm 1.39$ & $217.71 \pm 4.12$ & $40.64 \pm 0.76$ \\
\hline Uppar lagoon & $212.30 \pm 6.07$ & $43.63 \pm 1.03$ & $112.59 \pm 3.19$ & $22.59 \pm 0.53$ \\
\hline Batticaloa lagoon & $235.85 \pm 8.46$ & $49.87 \pm 1.77$ & $124.31 \pm 4.85$ & $25.38 \pm 0.98$ \\
\hline Pottuvill-Urani Lagoon & $201.96 \pm 2.65$ & $51.14 \pm 0.50$ & $113.71 \pm 1.06$ & $22.16 \pm 0.30$ \\
\hline
\end{tabular}




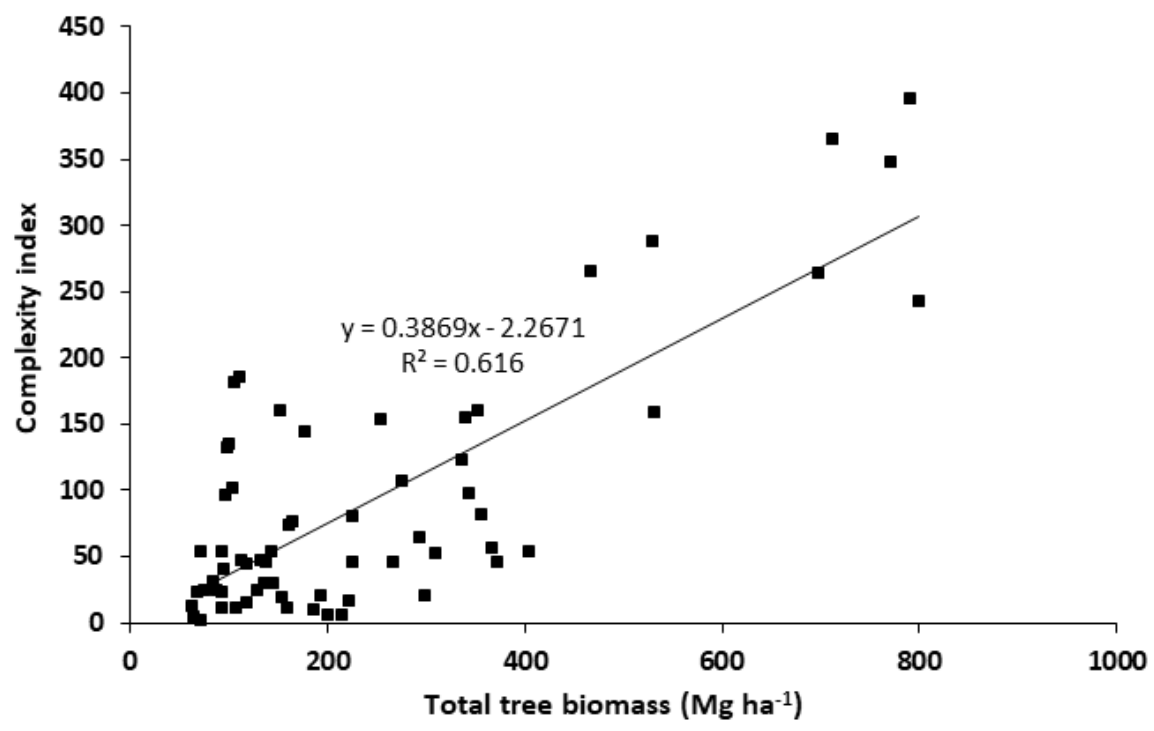

Figure 2: Relationship between vegetation structural complexity (CI) total biomass of mangroves.

Table 5: Species vise contribution to the maintaining of total organic carbon (TOC) stock in the vegetation of mangrove ecosystem at each study area

\begin{tabular}{|c|c|c|c|c|c|c|}
\hline \multirow{2}{*}{$\begin{array}{l}\text { Mangrove } \\
\text { species }\end{array}$} & \multicolumn{6}{|c|}{ Total (above and below ground) organic carbon content $\left(\mathrm{Mg} \mathrm{C} \mathrm{ha} \mathbf{C}^{-1}\right)$} \\
\hline & $\begin{array}{c}\text { Thondaimannaru } \\
\text { lagoon }\end{array}$ & $\begin{array}{l}\text { Nayaru } \\
\text { lagoon }\end{array}$ & $\begin{array}{l}\text { Yanoya } \\
\text { estuary }\end{array}$ & $\begin{array}{l}\text { Uppar } \\
\text { lagoon }\end{array}$ & $\begin{array}{c}\text { Batticaloa } \\
\text { lagoon }\end{array}$ & $\begin{array}{c}\text { Pottuvill-Urani } \\
\text { lagoon }\end{array}$ \\
\hline R. mucronata & $\begin{array}{l}4.75 \\
(5.3)\end{array}$ & $\begin{array}{l}42.10 \\
(38.2)\end{array}$ & $\begin{array}{l}13.84 \\
(5.3)\end{array}$ & $\begin{array}{l}23.08 \\
(17.0)\end{array}$ & & $\begin{array}{l}81.96 \\
(60.3)\end{array}$ \\
\hline R. apiculata & & & & & $\begin{array}{l}79.70 \\
(53.2) \\
\end{array}$ & \\
\hline B. gymnorrhiza & & & $\begin{array}{l}0.49 \\
(0.1)\end{array}$ & & & $\begin{array}{l}7.73 \\
(5.7)\end{array}$ \\
\hline A. marina & $\begin{array}{c}79.80 \\
(89.3)\end{array}$ & $\begin{array}{l}68.11 \\
(61.8)\end{array}$ & $\begin{array}{l}119.72 \\
(46.3)\end{array}$ & $\begin{array}{l}107.0 \\
(79.1)\end{array}$ & $\begin{array}{l}25.91 \\
(17.3)\end{array}$ & \\
\hline L. racemosa & $\begin{array}{l}4.80 \\
(5.3) \\
\end{array}$ & & $\begin{array}{l}9.26 \\
(3.5) \\
\end{array}$ & $\begin{array}{l}4.71 \\
(3.4) \\
\end{array}$ & & \\
\hline E. agallocha & & & $\begin{array}{l}49.81 \\
(19.2) \\
\end{array}$ & $\begin{array}{l}0.50 \\
(0.3)\end{array}$ & $\begin{array}{l}44.16 \\
(29.5)\end{array}$ & $\begin{array}{l}46.18 \\
(34.0)\end{array}$ \\
\hline C. decandra & & & $\begin{array}{l}2.46 \\
(0.9)\end{array}$ & & & \\
\hline A. corniculatum & & & $\begin{array}{c}0.29 \\
(0.11)\end{array}$ & & & \\
\hline H. littoralis & & & $\begin{array}{l}62.49 \\
(24.2)\end{array}$ & & & \\
\hline
\end{tabular}

*The percentage TOC contribution of each species within parentheses 


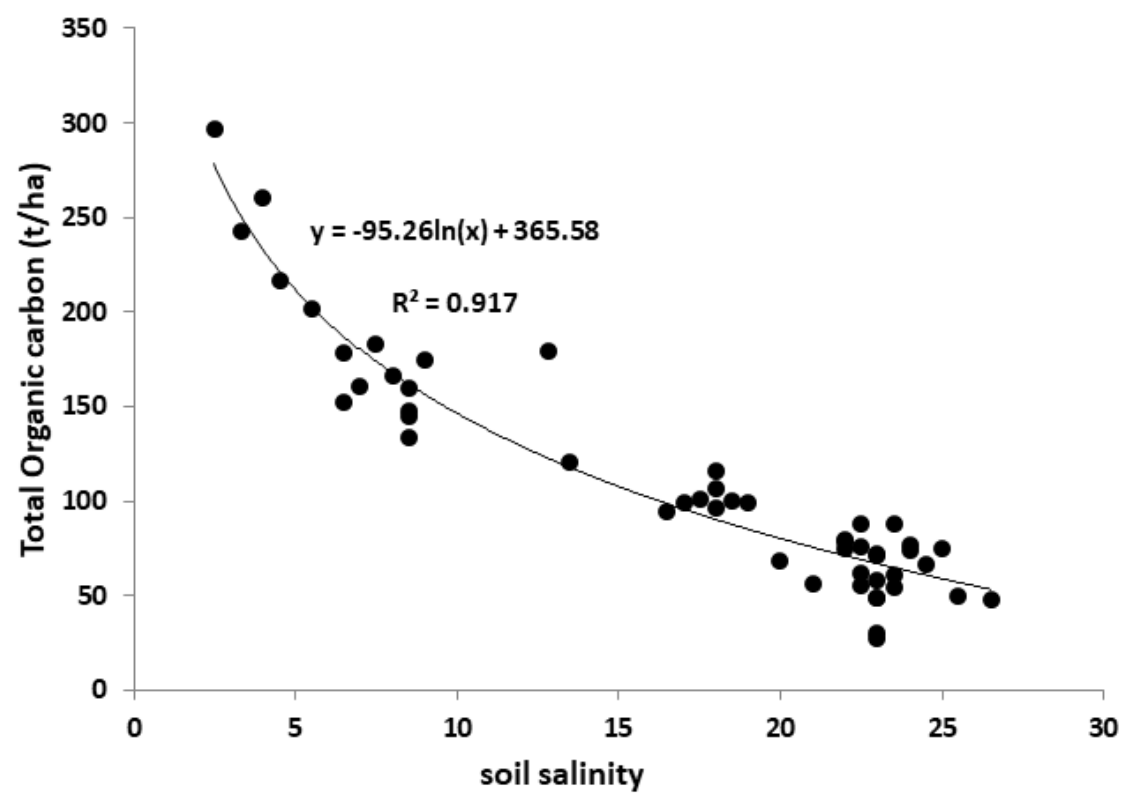

Figure 3: Relationship between TOC content in plant biomass and soil salinity of mangroves.

Data on TOC content in plant biomass and soil salinity of the study plots (total of 68) of all six study areas were pooled and analyzed. A strong positive correlation ( $p$ $<0.001)$ and a higher coefficient of determination $\left(\mathrm{R}^{2}=\right.$ 9.177) with non-liner relationship was observed for TOC and soil salinity of mangroves (Figure 3 ).

\section{DISCUSSION}

Rhizophora mucronata and Avicennia marina were the major constituent species in four study areas, Thondamannaru lagoon, Nayaru lagoon, Yanoya estuary and PottuvillUrani lagoon (Table 3). Comparable observations were reported by Amarasinghe and Balasubramaniam (1992), and Jayatissa et al. (2002), both species are common to many other dry zone mangrove ecosystems in Sri Lanka. A contradictory observation reported from Batticaloa lagoon with most common species were R.apiculata and E. agallocha and in Pottuvill-Urani lagoon, A.marina was not recorded (Table 3). This may be due to the variations in micro climatic and environmental conditions especially in the soil salinity levels. Based on the salinity data of the Batticaloa study area, revealed the low values compared with others. In general, observed species richness in mangrove areas on the west coast of Sri Lanka was greater than that on the northeast coast. Moreover, species richness in mangroves of the wet and intermediate zone was greater than that of the dry zone. Different publications explain that the distribution and establishment of mangroves are controlled by complex environmental factors. Including biotic and physico-chemical variables, which depend on geomorphic processes, determined the specific environmental conditions, with suitable mangrove species (Tomlinson 1986).

In addition to that, physiological tolerance to stresses including inundation and salinity levels, are some of the factors which have been reported to affect species distribution (Patterson and Mendelssohn 1991, McKee
1993, Chen and Twilley 1999).

A rare mangrove species, Ceriops decandra, was recorded in the present study at Yanoya mangrove ecosystem. In the National Red List 2012 of Sri Lanka, C. decandra was categorized under "Critically Endangered" species and added to the list of true mangroves recorded in Sri Lanka (personal communication). This may be the first-time scientific record of the $C$. decandra in the recent history of Sri Lanka. Higher values for species composition and diversity were recorded at Yanoya estuary (Table 3). Mean girth diameter (dbh) and height reported are also relatively high values explaining the healthy and luxuriant mangrove ecosystem among others in northeast coast of Sri Lanka.

Including above and below ground biomass and TOC embedded in plant biomass recorded northeast coast mangroves $158-416 \mathrm{Mg} \mathrm{ha}^{-1}$, and $89-257 \mathrm{Mg} \mathrm{C} \mathrm{ha}^{-1}$ respectively. These values are comparatively lower than that was reported by the west coast mangroves of Sri Lanka (Perera et al., 2012, Perera et al., 2013). This may due to the lower in stand densities of some areas, such as Thondamannaru and Pottuvill-Urani lagoon. Comparing the total biomass values recorded from the present study with worldwide mangrove areas, it revealed that most of the Sri Lankan north-east coast mangroves have higher biomass retention capacity than others (Table 6). In addition to that the above ground biomass values obtained from all the mangrove areas except Thondamannaru lagoon, were comparatively high than that of the mean value $(192 \mathrm{Mg}$ ha $^{-1}$ ) published by the IPCC (2013).

The mean above ground tree biomass of the northeast coast of Sri Lanka was $226.34 \mathrm{Mg} \mathrm{ha}^{-1}$ (Table 4), which was higher than the common values proposed for the Southeast Asia $\left(160-200 \mathrm{Mg} \mathrm{ha}^{-1}\right.$. The high tree biomass in the area has two possible explanations, one is that these north-east areas were highly isolated during last thirty years due to the civil war situation of the country. Very limited human 
Table 6: Comparison of plant biomass (Above and below ground) values revealed from present study with publish data from worldwide mangrove ecosystems

\begin{tabular}{|c|c|c|c|c|c|}
\hline \multirow[b]{2}{*}{ Study area } & \multirow[b]{2}{*}{$\begin{array}{c}\text { Common } \\
\text { mangrove species }\end{array}$} & \multicolumn{3}{|c|}{ Plant biomass } & \multirow[b]{2}{*}{ Reference } \\
\hline & & $\begin{array}{l}\text { Above ground } \\
\text { biomass } \\
\left(\mathrm{Mg} \mathrm{ha}^{-1}\right)\end{array}$ & $\begin{array}{c}\text { Below } \\
\text { ground } \\
\text { biomass } \\
\left(\mathrm{Mg} \mathrm{ha}^{-1}\right)\end{array}$ & $\begin{array}{c}\text { Total } \\
\left(\mathrm{Mg} \mathrm{ha}^{-1}\right)\end{array}$ & \\
\hline $\begin{array}{l}\text { Halmahera, } \\
\text { Indonesia }\end{array}$ & BG & 436.00 & 180.70 & 616.70 & Komiyama et al., (1988) \\
\hline Yanoya estuary, Sri Lanka & $\begin{array}{l}\mathrm{AM}, \mathrm{EA}, \mathrm{CD}, \mathrm{LR}, \\
\mathrm{RM}, \mathrm{HI}, \mathrm{BG}, \mathrm{AC}\end{array}$ & 386.69 & 74.30 & 460.99 & Present Study \\
\hline Northwestern Australia & RS, AM & 245.35 & 46.05 & 291.40 & Alongi, et al.,(2002) \\
\hline $\begin{array}{l}\text { Batticaloa lagoon, } \\
\text { Sri Lanka }\end{array}$ & EA, RA, AM & 235.85 & 49.87 & 285.72 & Present Study \\
\hline Thalassery estuary, Kerala, India & $\mathrm{AO}$ & 189.26 & 83.60 & 272.86 & Vinod, et al., (2019) \\
\hline $\begin{array}{l}\text { Uppar lagoon, } \\
\text { Sri Lanka }\end{array}$ & AM, RM, LR, EA & 212.30 & 43.63 & 255.93 & Present Study \\
\hline $\begin{array}{l}\text { Pottuvill-Urani Lagoon, Sri } \\
\text { Lanka }\end{array}$ & EA, RM, BG & 201.96 & 51.14 & 253.10 & Present Study \\
\hline $\begin{array}{l}\text { Oligohaline zone, Sundarbans, } \\
\text { Bangladesh }\end{array}$ & $\begin{array}{c}\mathrm{HF}, \mathrm{EA}, \mathrm{XM}, \mathrm{BS}, \\
\mathrm{AO}\end{array}$ & 154.80 & 84.20 & 239.00 & Kamruzzaman et al., (2017) \\
\hline $\begin{array}{l}\text { Nayaru Lagoon, } \\
\text { Sri Lanka }\end{array}$ & AM, RM & 189.51 & 40.07 & 229.58 & Present Study \\
\hline $\begin{array}{l}\text { Sofala Bay, Central } \\
\text { Mozambique, Africa }\end{array}$ & $\mathrm{AM}$ & 134.60 & 64.70 & 199.30 & Sitoe et al., (2014) \\
\hline Southern Satun, Thailand & $\mathrm{CT}$ & 92.00 & 87.50 & 179.50 & Komiyama et al., (2000) \\
\hline Ajuruteua Peninsula, Brazil & $\mathrm{AG}$ & 91.70 & 87.00 & 178.70 & Virgulino-Junior, et al., (2020) \\
\hline Hinchinbrook Channel, Australia & $\mathrm{RS}$ & 123.00 & 52.00 & 175.00 & Matsui (2004) \\
\hline Northwestern Australia & $\mathrm{AM}$ & 132.65 & 28.50 & 161.15 & Alongi et al., (2000) \\
\hline $\begin{array}{l}\text { Thondamannaru lagoon, Sri } \\
\text { Lanka }\end{array}$ & AM, RM, LR, EA & 131.78 & 25.75 & 159.53 & Present Study \\
\hline $\begin{array}{l}\text { Sawi bay, } \\
\text { Thailand }\end{array}$ & $\mathrm{RA}, \mathrm{AA}, \mathrm{CT}$ & 124.40 & 19.50 & 143.90 & Alongi and Dixon (2000) \\
\hline $\begin{array}{l}\text { Gazi Bay, } \\
\text { Kenya }\end{array}$ & $\mathrm{RM}$ & 62.70 & 18.00 & 80.70 & Tamooh et al., (2009) \\
\hline
\end{tabular}

AM - Avicennia marina; AO - Avicennia officinalis; AA - Avicennia alba; AG - Avicennia germinans; AC - Aegiceras corniculatum; BG - Bruguiera gymnorrhiza; BS - Bruguiera sexangula RM - Rhizophora mucronata; RA - Rhizophora apiculata; LR - Lumnitzera racemosa; EA - Excoecaria agallocha; CD - Ceriops decandra; HI - Heritiera littoralis; HF -Heritiera fomes; XM - Xylocapus mekongensis

intervention to the mangrove ecosystems facilitated to luxuriant tree structures resulted with high biomass levels. The second reason may be the relatively high species composition and species diversity in theses six study areas compared with other mangrove areas worldwide (Table 6). Analyzing data on mangrove vegetation structure and their biomass values revealed a statistically significant $(\mathrm{p}<0.05)$ positive linear relationship to occur between both variables (Figure 2). Considering the community structural variables of study areas in northeast coast of Sri Lanka, indicated high relative frequency values for Rhizophora species among others, common to all six study areas (Table 3), may be a root for high biomass values. Ong et al., (2004), reported the dominance of Rhizophora species, which has high above-ground biomass.

Global mangrove biomass distribution revealed that, high biomass values at lower latitude areas and decreases towards the high latitudes. Therefore, due the location of Sri Lanka, in lower latitude area, prevailing favorable climatic conditions, such as temperature, solar radiation and precipitation, facilitates to maintaining high biomass mangrove forests. The high tree biomass of mangrove forests obviously demonstrates the important role of mangrove forests as maintaining natural carbon sinks and thus in reducing carbon emissions (Siikamaki et al., 2012; Duarte et al., 2013). The results highlight the benefits of mangrove restoration for improving ecosystem carbon storage and reducing greenhouse gas (GHG) emissions (Duarte et al., 2013).

Many studies reported the salinity level is a driving force for distribution of mangroves (Chen and Ye, 2014; Dangremond, 2015; Kodikara et al., 2018), and plant species are well adapted to tolerate high salt levels in the intertidal substrate and salinity plays a vital role in their growth and productivity. Joshi and Ghose (2003) reported that maximum of the vegetation structural complexity 
(CI) of mangroves has been reported from the areas with lower salinity of the western Sundarabans. Salinity effects on plant growth was described by Jalil (2002), in three ways, by limiting the water availability against the osmotic gradient, by reducing nutrient availability, by causing accumulation of $\mathrm{Na}^{+}$and $\mathrm{Cl}^{-}$ions in toxic concentration causing water stress conditions, enhancing closure of stomata and reduced photosynthesis. Different soil salinity levels were recorded among total of sixty-eight study plots in six study areas, these values were then correlated with TOC capacity of the plot. A strong positive correlation $(p<0.001)$ with non-liner relationship was observed for TOC and soil salinity of mangroves (Figure 3), revealed that salinity in the substrate is highly effective to the TOC retention capacity of the mangroves. High salinity levels retain low TOC retention capacity, while High TOC retention capacity will record with low salinity mangrove substratum. These relationships can be improved and be more accurate by adding data from diverse environmental and physical conditions in Sri Lanka.

\section{CONCLUSION}

Highest species diversity and biomass values (159-460 Mg $\mathrm{ha}^{-1}$ ) were recorded at Yanoya followed by Thondamannaru and Uppar lagoons. A critically endangered mangrove species, Ceriops decandra, was recorded at Yanoya mangrove ecosystem. Average above ground biomass of the northeast coast of Sri Lanka was $226.34 \mathrm{Mg} \mathrm{ha}^{-1}$ which is higher than the common values proposed for the Southeast Asia (160 - $200 \mathrm{Mg} \mathrm{ha}^{-1}$ ). Statistically significant linear relationships occurred between, biomass and the vegetation structure as well as soil salinity and carbon retention capacity of mangrove. Results and findings of the present study assist to add new knowledge and rationalize the conservation and management of mangrove ecosystems at northeast coast of Sri Lanka, which were highly isolated during last three decades.

\section{ACKNOWLEDGMENT}

Authors are extremely grateful to W.A Sumanadasa, from NARA for his contribution on field data collection and Dr. S. Somaratne from Department of Botany, The Open University of Sri Lanka for his invaluable contribution to data analysis.

\section{DECLARATION OF CONFLICT OF INTEREST}

The authors declare that they have no competing interests.

\section{REFERENCES}

Aizpuru, M., Achard, F. and Blasco, F. (2000). Global assessment of cover change of the mangrove forests using satellite imagery at medium to high resolution. In: EEC Research project n 15017-1999-05 FIED ISP FR - Joint Research Centre, Ispra.

Aksornkoae, S. (1993). Ecology and Management of Mangrove. IUCN - The World Conservation Union, Bangkok, Thailand. https://portals.iucn.org/library/ sites/library/files/documents/WTL-024.pdf.
Alongi, D.M., Clough, B.F. and Dixon, P. (2002). Nutrient partitioning and storage in arid-zone forests of the mangroves Rhizophora stylosa and Avicennia marina . Trees 17: 51-60. DOI: 10.1007/s00468-002-0206-2.

Amarasinghe, M.D. and Balasubramaniam, S. (1992b). Structural properties of two types of mangrove stands on the nothernwestern coast of Sri Lanka. Hydrobiologia 247: 17-27.

Amarasinghe, M.D. and Perera K.A.R.S. (2017). Historical biogeography of mangroves in Sri Lanka. Ceylon Journal of Science (Special Issue) 46: 111-117. http:// doi.org/10.4038/cjs.v46i5.7458.

Bastiaanssen, W.G.M. and Chandrapala, L. (2003). Water balance variability across Sri Lanka for assessing agriculture and environmental water use agriculture water management. Agricultural Water Management. 58(2): 171-192. DOI: 10.1016/S0378-3774(02)001282.

Chen, R. and Twilley, R. R. (1999). Patterns of mangrove forest structure and soil nutrient dynamics along the Shark River estuary, Florida, Estuaries 22: 995-970. DOI: $10.2307 / 1353075$.

Chen and Ye, Y. (2014). Effects of salinity and nutrient addition on mangrove Excoecaria agallocha. PLoS ONE 9(4): e93337. doi:10.1371/journal.pone.0093337

Cintron, G. and Schaeffer-Novelli, S.Y. (1984). Methods for studying mangrove structure, In: S. C. Snedaker and J. Snadaker (Eds.), The Mangrove Ecosystem: Research Methods, UNESCO, Paris, Pp. 91-113.

Dangremond, E.M., Feller, Wayne, P. and Sousa, W.P. (2015). Environmental tolerances of rare and common mangroves along light and salinity gradients. Oecologia 179: 1187-1198 DOI 10.1007/s00442-015-3408-1.

Duarte, C., Losada, I. and Hendriks, I. (2013). The role of coastal plant communities for climate change mitigation and adaptation. Nature Climate Change 3: 961-968. https://doi.org/10.1038/nclimate1970.

Edirisinghe, E.A.P.N., Ariyadasa, K.P. and Chandani, R.P.D.S. (2012). Forest cover assessment of Sri Lanka. The Sri Lankan Forester (New series) 34: 1-12.

Harris, J.M and Vinobaba, P. (2013). Influence of hydrochemistry on biotic components of the Batticaloa lagoon. International Journal of Environmental Sciences 3: 1603-1613. doi:10.6088/ijes.2013030500030.

IUCN Sri Lanka and the Central Environmental Authority (2006). National Wetland Directory of Sri Lanka, Colombo, Sri Lanka.

Jalil, M.A. (2002). Impact of salinity on the growth of Avicennia officinalis and Aegicerus corniculatum. Dissertation submitted to Forestry and Wood Technology Discipline, Khulna University, Khulna, Bangladesh.

Jayakody, J.M.A.L., Amrasinghe, M.D., Pahalawattarachchi, V. and De Silva, K.H.W.L. (2008). Vegetation structure and potential gross primary productivity of mangroves at Kadolkallle in Meegamuwa (Negombo) estuary, Sri Lanka, Sri Lanka Journal of Aquatic Sciences 13: 95-108.

Jayatissa, L.P., Dahdouh-Guebas, F. and Koedam, N. (2002). A review of floral composition and distribution of mangroves in Sri Lanka. Botanical Journal of the 
Linnaeus Society 138: 29-43. https://doi.org/10.1046/ j.1095-8339.2002.00002.x.

Joshi, H. and Ghose, M. (2003). Forest structure and species distribution along soil salinity and $\mathrm{pH}$ gradient in mangrove swamps of the Sundarabans. Tropical Ecology 44(2): 197-206.

Kathiresan, K. and Khan, S.A. (2010). International Training Course on Costal biodiversity in Mangroves: Course manual, Annamalie University (CAS in Marine Biology, Parangipettai), India. 744 pp.

Kathiresan, K., Veerappan, $\mathrm{N}$ and Balasubramanian, R. (2015). Status of fauna in mangrove ecosystems of India, Marine Faunal Diversity in India 485-497. https://doi.org/10.1016/B978-0-12-801948-1.00029-X.

Kirui, B., Kairo, J.G. and Karachi, M., (2006). Allometric equations for estimating above ground biomass of Rhizophora mucronata Lamk. (Rhizophoraceae) Mangroves at Gazi Bay, Kenya. Western Indian Ocean Journal of Marine Science 5(1): 27-34. DOI: 10.4314/ wiojms.v5i1.28496.

Kodikara, K.A.S., Jayatissa, L.P., Huxham, M., DahdouhGuebas, F. and Koedam, N. (2018). The effects of salinity on growth and survival of mangrove seedlings changes with age. Acta Botanica Brasilica 32(1): 3746. DOI: 10.1590/0102-33062017abb0100.

Kotagama, S.W., Pinto, L. and Samarakoon, J.L. (1989). Country report Sri Lanka, In: Scott, D.A. (Complied), A Directory of Asian Wetlands, Ramsar Site information services, Biodiversity Ecological Networks, Wetlands International, Netherlands.

Komiyama, A., Poungparn, S. and Kata, S. (2005) Common allometric equations for estimating the tree weight of mangroves Journal of Tropical Ecology 21: 471-477.

Lacambra, C., Friess, D., Spencer, T. and Moller, I. (2013). Bioshields: mangrove ecosystems as resilient natural coastal defenses. In F. Renaud, K. Sudmeier-Rieux and M. Estrella (Eds.), The Role of Ecosystems in Disaster Risk Reduction: From Science to Practice. Tokyo: UNU Press. Pp 486. text_808710_9789280812213.pdf

Lugo, A.E. and Snedaker, S.C. (1975). Properties of a mangrove forest in southern Florida, In: G.E. Walsh, S.C. Snedaker and M.J. Teas (Eds.), Proceedings of the International Symposium on Biology and Management of Mangroves. Gainesville, Florida, USA, University of Florida. Pp. 170-212.

Ong, J.E., Gong, W. K. and Wong, C.H. (2004). Allometry and partitioning of the mangrove, Rhizophora apiculata. Forest Ecology and Management 188: 395-408.

Mc Kee, K.L. (1993). Soil physicochemical patterns and mangrove species distribution - reciprocal effects. Journal of Ecology 81: 477-487.

Patterson, C.S. and Mendelssohn, I.A. (1991). A comparison of physicochemical variables across plant zones in a mangal/salt marsh community in Louisiana. Wetlands 11: 139-161. https://doi.org/10.1007/BF03160845
Perera, K.A.R.S., Sumanadasa W.A. and Amarasinghe M. D. (2012). Carbon retention capacity of two mangrove species, Bruguiera gymnorrhiza (L.) Lamk. and Lumnitzera racemosa Willd. in Negombo estuary, Sri Lanka. Journal of the Faculty of Graduate Studies, 2012, University of Kelaniya, Sri Lanka 1: 56-70 http:// repository.kln.ac.lk/handle/123456789/5418

Perera, K.A.R.S. and Amarasinghe, M.D. (2013). Carbon partitioning and allometric relationships between diameter and total organic carbon (TOC) in plant components of Bruguiera gymnorrhiza (L.) Lamk. and Lumnitzera racemosa Willd. in microtidal estuary in Sri Lanka. International Journal of Marine Science 3: 7278. DOI:10.5376/ijms.2013.03.0009.

Perera, K.A.R.S. and M.D. Amarasinghe (2016). Atmospheric carbon removal capacity of a mangrove ecosystem in a micro-tidal basin estuary in Sri Lanka. Journal of Atmospheric Environment 134: 121-128. https://doi.org/10.1016/j.atmosenv.2016.03.034.

Prasanna, M.G.M, Ranawana, K.B. and Jayasuriya, K.M.G.G. (2019). Species composition, abundance and diversity of mangroves in selected sites in Amprara District in the east coast of Sri Lanka. Ceylon Journal of Science 48(2): 169-175. DOI: http://doi.org/10.4038/ cjs.v48i2.7621

Saenger, P. (2002). Mangrove ecology, silviculture and conservation. The Netherlands, Kluwer Academic Press. Pp 360. DOI:10.1007/978-94-015-9962-7

Silva, E.I.L., Katupotha, J., Amarasinghe, O., Manthrithilake, H. and Ariyaratna, R. (2013). Lagoons of Sri Lanka: from the origins to the present. Colombo, Sri Lanka: International Water Management Institute (IWMI). 122p. DOI: 10.5337/2013.215.

Saenger, P., Hegerl, E.J. and Davie, J.D.S. (1983). Global status of mangrove ecosystems. Commission on Ecology Papers No. 3. Gland, Switzerland, International Union for Conservation of Nature and Natural Resources (IUCN), Pp 92.

Siikamaki, J., Sanchirico, J.N. and Jardine, S.L. (2012). Global economic potential for reducing carbon dioxide emissions from mangrove loss. Proceedings of the National Academy of Sciences 109: 14369-14374. DOI: 10.1073/pnas.1200519109.

Spalding, M.D., Blasco, F. and Field, C.D. (eds.) (1997). World mangrove atlas, International Society of Mangrove Ecosystems, Okinawa, Japan. Pp178.

Tomlinson, P.B. (1986). The Botany of Mangroves. Cambridge University Press, Cambridge, U.K. Pp 413. 